\title{
Children Resilience In Dealing With Parental Divorce Based On the Ability to Regulate Emotions And Optimism
}

\author{
Febriady Huta Uruk ${ }^{1}$, Riska Ahmad ${ }^{1}$, Alwen Bentri ${ }^{1}$ \\ ${ }^{1}$ Universitas Negeri Padang \\ *Corresponding author, e-mail: febriadyhutauruk2@gmail.com
}

\begin{abstract}
Resilience is the ability of an individual to rise from adversity or the problems faced. It is needed in dealing with various bitter events such asparental divorce. To attainresilience, children need emotional and optimistic arrangements in dealing with problems. The purpose of this study, therefore, wasto examinechildren's resilience in the face of parental divorce based on the regulation of emotions and optimism. This wasa case study conducted in the city of Padang. The subjects in this study were two students with the criteria of having divorced parents in lessthan seven months or with the provision that the divorce occurred within the study period. Data analysis techniques usedwereinteractive models. The results showed resilience in children was different evenwhilefacing the same problem, such as parental divorce. For instance, one of the respondents,OT, had an excellent emotional arrangement while facing the parental divorce, while the other one, BT,was poor. The level of optimism in children also declined due to parental divorce.
\end{abstract}

Keywords: Resilience, Divorce, Parents, Regulating Emotions, Optimism.

How to Cite: Uruk, F.H., Ahmad, R., Bentri, A. (2020). Children Resilience In Dealing With Parental Divorce Based On the Ability to Regulate Emotions And Optimism. International Journal of Research in Counseling and Education, 4(1), 9-14.

\section{Introduction}

Individuals often face with bitter events and discouraging events in life and the ability to learn anddeal with these painful experiencesis essential for the overall wellbeing of a person (Albuquerque, Almeida, Cunha, Madureira, \& Andrade, 2015). For instance, resilient people are able to take lessons behind the problems whichoccur and regain normalcy(Dawson \& Pooley, 2013).These individuals also have the willingness to learn and adapt to conditions (Ifdil \& Taufik, 2012) as opposed to those a low level of resilience (Mehrinejad, Tarsafi, \& Rajabimoghadam, 2015). Maurović, Križanić, \& Klasić (2015) describes resilience as a dynamic process which includes a positive adaptation supported by the conditions around the individual, such as family, colleagues, and the surrounding community.

Resilience help individuals to achieve differentgoals in their lives (Reivich \& Shatte, 2002). Additionally, with the resilience of individuals might be able to maintain mental health conditions and improve their ability to walkout of the difficulties experienced (Lou, Taylor, \& Folco, 2018). To recover from stressful, traumatized and risky conditions, resilience skills including skills to form relationships, problem-solving skills, abilities in self-development, and the ability to understand and design the future are necessary. Reivich \& Shatte (2002) stated seven aspects of resilience, including (1) emotional regulation (emotion regulation), (2) impulse control, (3) optimism, (4) ability to analyze problems, (5) empathy, (6) self-efficacy, and (7) reaching out. This is in line with Desmita (2014) which stated that resilient adolescents have social competence andlife skills, such as problem-solving, critical thinking, taking the initiative, awareness of goals, and positive future predictions for themselves. Moreover, they have special interests, directed goals, and motivations for achievement in school and life in general.

Family problem is one of the conditions requiringstudents to be resilient. In general, a family is the primary developmentenvironment sincechildren start life and grow from the existing relationships. For instance, the links which benefit children includethe interrelationbetween parents and children,and father,mother, and child interactionswith other family members living together (Omoruyi, 2014). In the 
family, the child obtains the primary education from the parents, the basis for development and life in the future. For this reason, parents play a critical role in the development of children (Aressa, Nirwana, \& Bentri, 2016). Family conditions characterized bydisputes compromisesthe role of parents in this regard (Savitri, 2016). If a conflict between parents is not addressed, it might lead to divorce. Separation of parents is more damaging to children and family relationshipssince the adjustment period for divorce is longer and more difficult for the child than compared to the death of the parent. Most children go through five stages in this adjustment, includingrejection of divorce, anger directed at those involved in the situation, bargaining to unite parents, depression, and ultimately acceptance (Hurlock, 2011). Besides, separation caused by divorce is a severe problem since childrentend to be different in peer groups.

The impact of parental divorce is very diverse and complex (Cui, Fincham, \& Durtschi, 2011). According to Stahl, it has a negative impact, such as making an academic failure, irregularities in eating and sleeping, suicide, juvenile delinquency, drug abuse, fears of family loss, feeling guilty, angry, and depression (Aminah, Andayani, \& Karyanata, 2012; Nadeak, 2014). The signs of depression in adolescents according to (Ramadhani \& Retnowati, 2013) includechanges in mood or loss of interest in all activities, sadness, looking unhappy, fussy, complaining, and irritable. This is in line with Brooks (2011) explaining that in case a divorce occurs, achild experiencesan emotional reaction whichusually happens irrespective of the age, including sadness, fear, depression, anger, and confusion. Symptoms of depression, stress, anxiety, and other psychological disorders arise sincechildren are not in a position to manage their emotionseffectively. However, in the face of parental separation, each child is expected to demonstrate the ability to regulate emotions.

Adolescents who are able to manage their emotions deal with stress in their lives, and this forms the basis ofaddressing challenges in the future with propermental health (Silvers et al., 2012). Individuals who are in a positionto manage their emotions well have low depression symptoms and have a higher cognitive reassessment (Rusk, Tamir, \& Rothbaum, 2011). Importantly, emotional regulation is the individual's ability to control deep feelings and emotions. It is central to the correlation between behavior and emotions among adolescents. Teenagers with low emotional regulation oftenexperience various forms of adolescent psychopathology, both from internal and external disorders. Internalconditions include depression, stress, sadness, and anxiety, while external disorders are characterized by dysregulation and anger. The excessive intensity of sadness in adolescents is closely related to depressive symptoms, while extreme anger is related to behavioral problems.

Furthermore, children from divorced families tend to experience academicdifficulties, external issues, such as voicing feelings and delinquency, and internal problems, includinganxiety and depression. Besides, they often show a lack of social responsibility, poorintimate relationships, dropping out of school, dealing with antisocial peers, have a lowlevel of self-worth. According to Aziz (2015); Pratama, Syahniar, \& Karneli (2016), victims of broken homesfearteachers since they are considered harmful and aggressive, violating school rules, speaking harshly, resisting/opposing, not moral orpolite, lazy to go to school, like being truant, do not like learning, oftenmake noise andseek attention, anddisturb friends and teachers. Furthermore, children lose concentration during learning as a result of the separation between parents, leading to anacademic failure (Rahmi, Mudjiran, \& Nurfarhanah, 2014; Tumiyem, Daharnis, \& Alizamar, 2015). These impacts show theoptimism for adolescents is low due to the lack of acceptance of divorce by their parents.

People with an optimistic outlook in dealing with problems believe failure is a temporary matter. Contrastingly, the less optimistic individualstry to withdraw, become passive, and give up easily in achieving their goals. The low level of optimism is caused by negative self-beliefs based on wrong thinking (Nurindah \& Afiatin, 2012). Optimism is related to positive feelingswhich have an impact on good morals, perseverance, practical problem solving, academics, athletics, military, work, political success, popularity, better health, and being free from stress and trauma. Conversely, low optimism is a sign of depression, passivity, failure, social estrangement, and raises the possibility of illness and death.

Indisputably, optimism is crucial for individuals facing various problems, such as divorce. Children with low optimism hardlysucceed in overcoming issues emanating from the separation between parents and think the problem disrupts all aspects of their lives in academics, health, psychological, and behavioral. Furthermore, they areoftenunhappy and lack purpose in life due to the issue of parental separation (Primasti \& Wrastari, 2013). This condition, if left unchecked,cause various problems laterin life.

Nevertheless, not all children with divorced parents experience the problems discussed above. Some have excellent achievements and are positive despite experiencing stress and conflict. This assertionis in line with Dewi \& Hendriani (2014), which states that the ability of resilience in each teenager is different, even where they face similar problems such as parents' divorce. Children who are in a non-conducive environment have positive developments despite their unpleasant experiences. This depends on how the howone walk out of the problems and pressures experienced. It is essential for young ones with divorced parents to have positive abilities in responding to challenges, which is commonly referred to as resilience. According toHadianti, Salsabila Wahyu, Nurwati, R. Nunung \& Darwis (2017), resilience is necessary in casea teenager is faced with parental divorce since it minimizes the negative impacts and helps them develop positively. A counselor teacher has a vital role in developing students' resilience. The purpose of Guiding and Counseling (BK) is 
increasingly crucial in schools, especially in overcoming the difficulties experienced by students, both in learning and personalissues. BK services include coaching in areas related to the development of personal, social, education, and career life. Therefore, through various BK services, emotional and optimistic arrangements which are part of personal experience are improved, especially for students in the face of parental divorce.

In light of the above, emotional and optimism arrangement is much needed by achild facing problems. For this reason, this study aims at analyzing children's resilience while facing parental divorce in terms of regulating emotions and optimism.

\section{Method}

This wasa case study exploring real-life situations through detailed and in-depth data collection withvarious sources of information (for example, observations, interviews, audiovisual materials, documents, and various reports) and reports in the description of the case (Creswell, 2015).

The studywas conducted in the city of Padang and involved two students having divorced parents in less than seven months. The subject of this research is adapted to the purpose of study or specific considerations (Satori \& Komariah, 2014), and the whole study took three months (November 2018 - January 2019). Retrieval of additional informants using the snowball sampling technique, the data source samplingapproach.

The data collection techniques include observations by researchers without being directly involved in activities. Theresearchers were non-participant observers on the resilience of divorced parents. Additionally, interviews wereconducted through direct communication between interviewers and thespeakers (Bungin, 2015). Thewritten interview guideline instruments containing questions tobe asked to informants about the resilience of divorced parents were used (Gunawan, 2014).

To guarantee the validity of the technical data used, a credibility test was usedfollowing the provisions in the case study research, which requires what is obtained to be in line with the desired context. In with this goal, several measures were taken, including maintaining the familiarity of researcher with the subject and the informant, the perseverance of the observer, triangulating, and asking colleagues who did not take part in the research.

The data analysis technique used was an interactive model (Megawati, 2016) which consists of three activity lines including (1) data reduction, (2) data display, (3) drawing conclusions and data verification.

\section{Results and Discussion}

1. Regulating Emotions.

Emotional regulation is the ability to always be calm in a state filled with pressure (Reivich \& Shatte, 2002).It makes it easier for individuals to solve various problems since it imparts the ability to control negative feelings (Asriandari, 2015). According to Reivich \& Shatte (2002), individuals who are able to express their emotions appropriately and well are resilient.

The results of this study show OT and BT have different emotional arrangements while facing parental divorce. After the parents divorced, the child remained in his old environment and therefore did not need to adapt, and only needed to adjust to the absence of his father at home. Moreover, neighbors who still have a relationship with OT also know and understand the conditions resulting from parental divorce, and this was a source of strength. At the time the parents divorced, OT did not show his sadness and disappointment to others. During the interview, the child looked stern and tried to cover up his grief andrecounts the condition of his parents' divorce openly. Based on the above information, OT understands the reason for his parent's divorce, and this helped to avoid dwelling on sadness for long, an assertion confirmed by the mother. Even so, the mother understood how sad it was, though the child behaved as usual. OT was alsofaced with the problem of not having a batik uniform like other friends. The batik uniform could no longer be used, and the mother did not have money to buy new clothes. Even though they don't have batik uniforms like other friends, OT doesn't feel angry with her mother.

Apart from interviews, observations were also made at OT's home. After the divorce, the economic statusof the OT family declined significantly, and as a result, themother must work hard to meet family needs. This condition makes her busy and sometimes prepares food late, a state the son understands. In an attempt to solve the problem, OT often visits the brother's house. From these conditions, it appears that OT has proper emotional regulationand understands the difficulties emanating from parental divorce, as well as the consequencesit has.

After his parents divorced and thesister moved to thematernal grandmother's place,BT was forced to adapt to thenew environment. This situation led to depressiondue to separation from the father and friends. Upon learning of the parental divorce, BTcried bitterly and stayed locked in the room. The child never liked the separation and would wish parents toreunite. This desire was seen from the sadness while talking to the researchers about the divorce. The mother confirmed the devastation caused by the divorce, 
a condition which led to anxiousness in the family. In the end, BT was permitted to visit the father every school holiday. Following the divorce, the child became moody, not as cheerful as before.Additionally, the child became less enthusiastic about learning, and this affected the academic performance. This condition indicates that it has a poor emotional arrangement. The response to the divorce was negative, and this could be seen as the child tried to express to narrate the experience. At the time of the study, he was still not into terms with what had happened.

The problemof emotional regulation, especially in the caseof parental divorce, affect the lives of children in the future. Therefore, there is a need for collaboration between people around to give attention and understanding for children tohave good emotional response while facing difficulties.

2. Optimism.

Individuals with good resilience are optimistic andbelieve things change for the better (Roellyana \& Listiyandini, 2016). Optimism is an aspect of strength, and according to Slamet (2014), it is an attitude of individuals characterized bystrong hopes for everything, even whileconfronted with difficulties.

Based on the results, OT and BT lack optimism in planning the future. For instance, OT aspires to bea soldier, but with financial statusdeclining followingthe divorce, there are doubts about achieving this dream. According to the child,the father never provided money to make ends meet, and therefore, the mother had to work alone. With these conditions,the aspirations to be a soldier in the future would not be achieved, and does not want to burden his mother with such endeavors. Evidently, the child is no longer optimistic about achieving his dream due to the deterioration of the family's financial status. Furthermore, OT is also not optimistic aboutcompleting school assignments. From the results of the interviews and observations, OT often fails to do assignments and prefers to cheat due to failure to understand the tasks given. This assertion wasconfirmed by his mother, who no longer supervise the child due to a busy working schedule. For this reason, it was established that OT had reduced optimism after his parents divorced. If this condition is left unchecked, it is likely toaffect even more in the future.

Similarly, BT haslow optimism when it comes to achieving hisgoals and lacked future aspirationsas a result of parental divorce. This condition also affected the urge to complete school assignments. The child confessed to cheating on friends' assignments at school not only due to lack of understandingbut also is laziness. Besides, BT lived in an overcrowded, making it challenging to study at home. According to his mother, hewas rarely seen studying and doing assignments at home but often play. Even though the mother attempts to encourage them to study, there is no evidence of change. His mother attributes these changes to the divorce. Undeniably, parental divorce affected the boy's optimism significantly.

The experiences of OT and BT indicates the role of counselors as professional staff in schools is increasingly essential. Counselors need to pay attention to students, especially those who experience parental divorce problems. Through guiding and counseling services, students are expected to have proper emotional and optimistic arrangements to overcomevarious challenges, including the difficulties brought about by parental divorce.

\section{Conclusion}

Children have different resilience abilities in dealing withparental divorce. Resilience, in this context,is the ability possessed by children to rise from adversity caused by parental divorce. Resilience has several aspects, including regulating emotions and optimism. Proper emotional regulation reduces excessive stress in children while facing social and emotional problems. With an optimistic attitude, the child has the confidence to walk out of the problem and attain career goals.

Resilience based on emotional regulation and optimism involvesrelating to emotional regulation due todivorced parents, and children express it differently.For instance, OT just kept quiet and tried to stay strong due to the environmental. After the parents divorced, the child remained in the same place. Also, neighborsmaintained a good relationship and understood the effectsof divorce. This condition gave OT strength until to be in terms with the divorce.Contrastingly, BT had to move immediately the parents divorced, and therefore, he had to adapt to the new environment.He was affected by the divorce negatively and kept wishing that the parents reunite.

Furthermore, the optimism of children after their parents divorced decreased. For instance, OT wasless optimistic about his dream of becoming a soldier, primarily due to the deterioration of his family's financial condition after the divorce. Additionally, he was also lessoptimistic in completing school assignments and preferred cheating. Similarly, BT did not have enthusiasm for attaining future goals; as a result, parents' divorce. Also, there was low optimism in completing school assignments, preferring to cheat.

\section{References}

Albuquerque, C., Almeida, J., Cunha, M., Madureira, A., \& Andrade, A. (2015). Protective Resilience Factors in Institutionalised Portuguese Adolescents. Procedia - Social and Behavioral Sciences, 171, $276-283$. 
Aminah, Andayani, T. R., \& Karyanata, N. A. (2012). Proses Penerimaan Anak (Remaja Akhir) terhadap Perceraian Orangtua dan Konsekuensi Psikososial yang Menyertainya. Jurnal IImiah Psikologi Candrajiwa, 1(3), 1-11.

Aressa, V., Nirwana, H., \& Bentri, A. (2016). Komunikasi Interpersonal Anak dan Orangtua ditinjau dari Jenis Kelamin , Tingkat Pendidikan Orangtua, dan Daerah Tempat Tinggal serta Implikasinya pada Bimbingan dan Konseling. Jurnal Konselor, 5(3), 139-150.

Asriandari, E. (2015). Resiliensi Remaja Korban Perceraian Orangtua. Jurnal Bimbingan Dan Konseling, 4(9), 18.

Aziz, M. (2015). Perilaku Sosial Anak Remaja Korban Broken Home dalam Berbagai Perspektif. Jurnal AI Ijtimaiyyah, 1(1), 30-50.

Brooks, J. (2011). The Process of Parenting(Kedelapan; R. Fajar, ed.). Yogyakarta: Pustaka Pelajar.

Bungin, B. (2015). Sosiologi Komunikasi. Jakarta: Kencana Prenada Media.

Creswell, J. W. (2015). Penelitian Kualitatif dan Desain Riset. Yogyakarta: Pustaka Pelajar.

Cui, M., Fincham, F. D., \& Durtschi, J. A. (2011). The effect of parental divorce on young adults' romantic relationship dissolution: What makes a difference? Personal Relationships, 18(3), 410-426.

Dawson, M., \& Pooley, J. A. (2013). Resilience: The Role of Optimism, Perceived Parental Autonomy Support and Perceived Social Support in First Year University Students. Journal of Education and Training Studies, 1(2), 38-49.

Desmita. (2014). Psikologi Perkembangan Peserta Didik. Bandung: Remaja Rosdakarya.

Dewi, N. R., \& Hendriani, W. (2014). Faktor Protektif untuk Mencapai Resiliensi pada Remaja Setelah Perceraian Orangtua. Jurnal Psikologi Klinis Dan Kesehatan Mental, 3(3), 37-43.

Gunawan, I. (2014). Metode Penelitian Kualitatif. Jakarta: Bumi Aksara.

Hadianti, Salsabila Wahyu, Nurwati, R. Nunung \& Darwis, R. S. (2017). Resiliensi Remaja Berprestasi dengan Latar Belakang Orangtua Bercerai. Jurnal Penelitian \& PKM, 4(2), 223-229.

Hurlock, E. B. (2011). Psikologi Perkembangan: Suatu Pendekatan Sepanjang Rentang Kehidupan. (V; I. \& Soedjarwo, ed.). Jakarta: Erlangga.

Ifdil, \& Taufik. (2012). Urgensi Peningkatan dan Pengembangan Resiliensi Siswa Di Sumatera Barat. Jurnal IImiah IImu Pendidikan, XIX(2), 115-121.

Lou, Y., Taylor, E. P., \& Folco, S. Di. (2018). Resilience and Resilience Factors in Children in Residential Care: A Systematic Review. Children and Youth Services Review, 1-50.

Maurović, I., Križanić, V., \& Klasić, P. (2015). Form Risk to Happiness: The Resilience of Adolescents in Residential Care. Kriminologija \& Socijalna Integracija, 22(2), 25-47.

Megawati, F. (2016). Kesulitan Mahasiswa dalam Mencapai Pembelajaran Bahasa Inggris secara Efektif. Jurnal Pedagogia, 5(2), 147-156.

Mehrinejad, S. A., Tarsafi, M., \& Rajabimoghadam, S. (2015). Predictability of Students' Resiliency by Their Spirituality. Procedia - Social and Behavioral Sciences, 205, 396-400.

Nadeak, T. F. S. (2014). Fenomena "Anak Nakal” Di Rungkut-Surabaya. Paradigma, 2(2), 1-6.

Nurindah, M., \& Afiatin, T. (2012). Meningkatkan Optimisme Remaja Panti Sosial dengan Pelatihan Berpikir Positif. Journal Intervensi Psikologi, 4(1), 57-76.

Omoruyi, I. V. (2014). Influence of Broken Home on Academic Performance and Personality Development of the Adolescents in Lagos State Metropolis. European Journal of Educational and Development Psychology, 2(2), 10-23.

Peterson, C., \& Seligman, M. E. P. (2004). Character Strengths and Virtues: A Handbook and Classification. Washington DC: APA.

Pratama, R., Syahniar, \& Karneli, Y. (2016). Perilaku Agresif Siswa dari Keluarga Broken Home. Jurnal Konselor, 5(4), 238-246.

Primasti, K. A., \& Wrastari, A. T. (2013). Dinamika Psychological Wellbeing pada Remaja yang Mengalami Perceraian Orangtua Ditinjau dari Family Conflict yang Dialami. Jurnal Psikologi Kepribadian Dan Sosial, 
2(3), 120-127.

Rahmi, S., Mudjiran, \& Nurfarhanah. (2014). Masalah-Masalah Yang Dihadapi Siswa Yang Berasal Dari Keluarga Broken Home Dan Implikasinya Terhadap Program Layanan Bimbingan Dan Konseling. Jurnal Konselor, 3(1).

Ramadhani, A., \& Retnowati, S. (2013). Depresi Pada Remaja Korban Bullying. Jurnal Psikologi, 92), 73-79.

Reivich, K., \& Shatte, A. (2002). The Resilience Factor; 7 Essential Skill For Overcoming Life's Inevitable Obstacle. New York: Broadway Books.

Roellyana, S., \& Listiyandini, R. A. (2016). Peranan Optimisme terhadap Resiliensi pada Mahasiswa Tingkat Akhir yang Mengerjakan Skripsi. Prosiding Konferensi Nasional Peneliti Muda Psikologi Indonesia, 1(1), 29-37.

Rusk, N., Tamir, M., \& Rothbaum, F. (2011). Performance and Learning Goals for Emotion Regulation. Motivation and Emotion, 35, 444-460.

Satori, D., \& Komariah, A. (2014). Metodologi Penelitian Kualitatif. Bandung: Alfabeta.

Savitri, D. \& A. (2016). Peran Keluarga dan Guru dalam Membangun Karakter dan Konsep Diri Siswa Broken Home Diusia Sekolah Dasar. Jurnal Pendidikan, 1(5), 861-864.

Silvers, J. A., Mcrae, K., Gabrieli, J. D. E., Gross, J. J., Remy, K. A., Ochsner, K. N., ... Ochsner, K. N. (2012). Emotion Age-Related Differences in Emotional Reactivity, Regulation, and Rejection Sensitivity in Adolescence Age-Related Differences in Emotional Reactivity , Regulation, and Rejection Sensitivity in Adolescence. Jurnal of American Psychological Association, 12(6), 1235-1247.

Slamet. (2014). Pelatihan Motivasi Berprestasi Guna Meningkatkan Efikasi Diri dan Optimisme pada Mahasiswa Aktivis Organisasi Di UIN Sunan Kalijaga Yogyakarta. Jurnal Hisbah, 11(1), 75-98.

Tumiyem, Daharnis, \& Alizamar. (2015). "Analisis terhadap Siswa yang Berasal dari Keluarga Broken Home" (Studi Kasus Di SMK Negeri 2 Gunung Talang). Jurnal Konselor, 4(3), 120-129. 